\title{
Meanderovaleichnus huenickeni ichnogen. et ichnosp. nov. from the Bajo de Véliz Formation (Upper Carboniferous-Permian), Argentina: a new case of worm-type burrowing
}

\section{Carlos CÓNSOLE-GONELLA* \& Florencio G. ACEÑOLAZA}

Instituto Superior de Correlación Geológica (INSUGEO), Universidad Nacional de Tucumán, Miguel Lillo 205, CP. 4000, Tucumán, Argentina; carlosconsole@csnat.unt.edu.ar

* Corresponding author

Cónsole-Gonella, C. \& Aceñolaza, F.G. 2014. Meanderovaleichnus huenickeni ichnogen. et ichnosp. nov. from the Bajo de Véliz Formation (Upper Carboniferous-Permian), Argentina: a new case of worm-type burrowing. [Meanderovaleichnus huenickeni ichnogen. et ichnosp. nov. de la Formación Bajo de Véliz (Carbonífero Superior-Pérmico), Argentina: un nuevo caso de excavación de un gusano]. Spanish Journal of Palaeontology, 29 (1), 51-60.

\begin{abstract}
A new ichnofossil, Meanderovaleichnus huenickeni ichnogen. et ichnosp. nov., is described from the fluviolacustrine deposits of the Bajo de Véliz Formation (Upper Carboniferous-Permian). The trace fossil consists of meanders (epichnial) with regular constrictions of variable width along the course. It is interpreted as a locomotion trace (repichnion) due to peristaltic burrowing of a worm, probably an annelid.
\end{abstract}

Keywords: Ichnology, Upper Paleozoic, Argentina, Meanderovaleichnus huenickeni, repichnia.

\section{RESUMEN}

Un nuevo icnofósil, Meanderovaleichnus huenickeni ichnogen. et ichnosp. nov., es descrito en los depósitos fluvio-lacustres de la Formación Bajo de Véliz (Carbonífero SuperiorPérmico). La traza fósil consiste en meandros (epichnia) con constricciones regulares de ancho variable a lo largo de la pista. Es interpretada como una traza de locomoción (repichnion) producto de la excavación peristáltica de un gusano, probablemente anélido.

Palabras clave: Icnología, Paleozoico Superior, Argentina, Meanderovaleichnus huenickeni, repichnia. 


\section{INTRODUCTION}

Understanding the palaeobiological factors influencing trace fossils is one of the main goals of ichnology, particularly as regards recognizing the tracemaker, the mode of construction, and its ethology (Seilacher, 2007; Gibert \& Ekdale, 2010). Possible locomotion and burrowing modes for invertebrates includes peristalsis, which is especially interesting as it has been adopted by diverse groups over the course of time. In the specific case of organisms with a vermiform body plan, this mechanism can be inferred through the ichnological record, although clear peristalsis indicators are commonly absent (Buatois \& Mángano, 2011), which circumstance makes the present report of particular interest. The material analysed in this study is from the Bajo de Véliz Formation (Upper CarboniferousPermian), in the province of San Luis, Argentina. This unit is world-renowned for its fossil content, including an abundant record of Gondwana flora and a significant record of insects and arachnids, all of which indicate a fluviolacustrine setting for the formation. The aim of this paper is to describe Meanderovaleichnus huenickeni ichnogen et ichnoesp. nov., interpreted as peristaltic burrowing of a worm-like organism (probably an annelid) based on its morphological and construction characteristics.

\section{GEOLOGICAL AND STRATIGRAPHIC SETTING}

The Gondwana site of Bajo de Véliz lies in the northwestern sector of the Sierra Grande de San Luis, about $25 \mathrm{~km}$ west of the Santa Rosa locality. It occupies a narrow graben about $12 \mathrm{~km}$ long oriented south to north and occupied by the Cautana Creek (Fig. 1). The section is located at $32^{\circ} 18^{\prime} 41^{\prime \prime} \mathrm{S}-65^{\circ} 24^{\prime} 48^{\prime \prime}$ (Fig. 2).

The Upper Carboniferous-Permian sedimentary deposits are surrounded by igneous and metamorphic rocks ranging from the Upper Precambrian to the Carboniferous. The Bajo de Véliz Formation, named after the locality, was defined by Flores (1969) and then studied in greater detail by Hünicken \& Pensa (1972), who estimated a geological column that is $168 \mathrm{~m}$ thick. It is represented by a siliciclastic sequence primarily comprising greenishgrey sandstones and lutites (Fig. 3).

Hünicken \& Pensa (1981) and Hünicken et al. (1981) recognize three members based on their lithological features. They are, from bottom to top: Cautana, Pallero and Lomas members. The 102 m-thick Cautana Member starts with a basal polymictic conglomerate that grades upwards to fine-grained sandstones intercalated with greenish-grey siltstones, capped by arkosic sandstones and banks of greenish siltstones.
The next member above, the Pallero Member (Hünicken \& Pensa, 1972) consists of $53 \mathrm{~m}$ of wellstratified fine-grained sandstones and greenish limolites containing abundant fossil remains, marlekor structures (flat concretions) and local dropstones. This member has provided well-preserved fossil plants, such as Gangamopteris obovata, Glossopteris sp. and Samaropsis kurtzi, palynomorphs, such as Clogranisporites patelliformis and Acantotriletes filiformis, insects, and arachnids. In fact, this unit is famous for having yielded the renowned Megarachne servinei Hünicken, 1979, a bizarre eurypterid, similar to rare forms known from Carboniferous rocks of Scotland and South Africa (after Selden et al., 2005; Selden \& Penney, 2010). The trace fossil described herein is found in these levels. Overall, its sedimentology and flora associations indicate a mixed, fluvio-lacustrine setting (Hünicken et al., 1981).

The sequence is crowned by medium to coarsegrained yellowish to dark-greenish sandstones defined by Hünicken \& Pensa (1972) as the Lomas Member. The entire sedimentary complex is located within a graben that is cut in basment phyllites of the San Luis Formation (Prozzi \& Ramos, 1988).

\section{SYSTEMATIC ICHNOLOGY}

The criteria for description and interpretation follows Bromley (1981) and Bertling et al. (2006).

Ichnogenus Meanderovaleichnus ichnogen. nov.

Derivatio nominis. Latin, meander, meandering; ovale, ovals; ichnos, trace.

Type ichnospecies. Meanderovaleichnus huenickeni ichnosp. nov.

Diagnosis. Meandering to straight horizontal, epichnial structure, with non meniscate active fill, without walls. It is semi-circular in cross-section, with regularly spaced constrictions, perpendicular to the direction of the trace course, which can be visible as variably sized asymmetric ovals in plan view.

\section{Ichnospecies Meanderovaleichnus huenickeni ichnosp. nov.}

Derivatio nominis. Named after Dr. Mario Hünicken, who discovered the material described herein.

Type material. One specimen, the holotype: PIL 15.769. A slab (Fig. 4), from the Bajo de Véliz Formation 


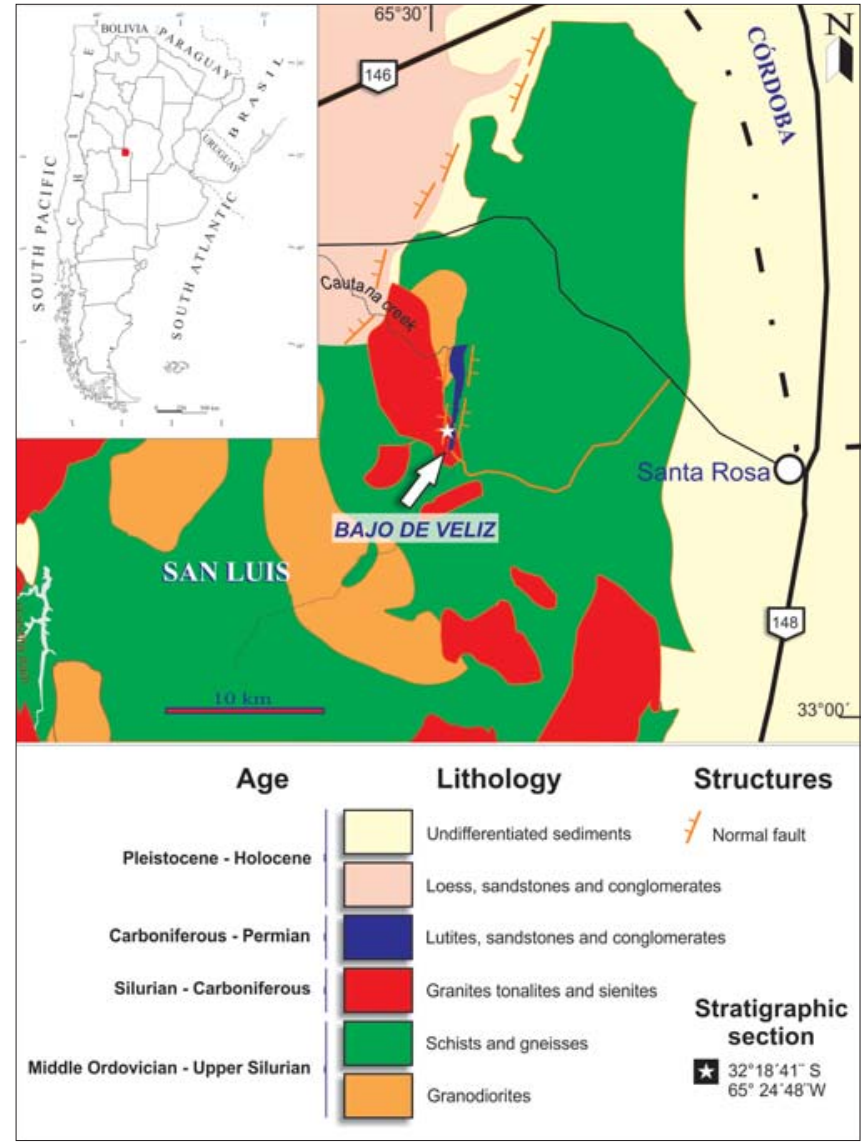

Figure 1. Simplified geological map of the study area (after Sato et al., 2003 and Hünicken et al., 1981). The arrow points to the Bajo de Véliz locality.

(Upper Carboniferous-Permian), norther part of the San Luis Province, Argentina. Deposited in the Paleontología Invertebrados Lillo collection (prefix PIL).

Diagnosis. As for the ichnogenus.

Description. The trace fossil is preserved as a negative epirelief on the surface of a finely laminated grey lutite (Fig. 4a). It is a continuous structure, primarily parallel to the bedding or slightly inclined. The margins are sharp. The orientation in plan view ranges from straight to highly meandering. In cross-section, it is semi-circular to slightly semi-ovoid. There are complete self-crossings that produce nodes (Figs $4 \mathrm{~b}-\mathrm{c}$ ) that can cross-cut pre-existing trajectories (Fig. 4c). It ranges in width from 0.4 to $1 \mathrm{~cm}$. The trace fossil displays regularly distributed gradual constrictions and swellings, forming small, interconnected 'ovals' in plan view (Figs 4a-f). The constrictions are of varying size in different parts of the section. Most constrictions are asymmetric, suggesting the organism's direction of movement (see 'Trace construction' section in DISCUSSION). True branchings do not occur, although over-crossings are common, which produce false branching

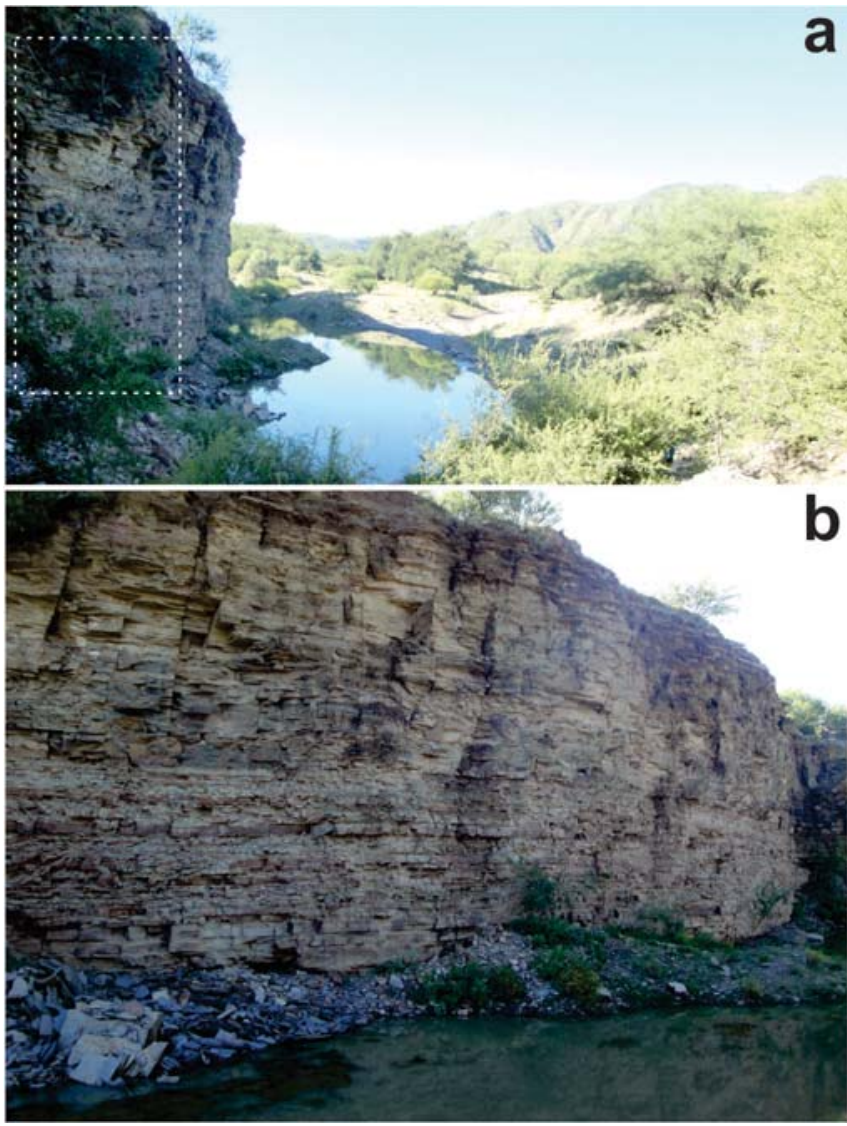

Figure 2. Outcrop photographs of the Pallero Member section. a) Panoramic view. b) Detailed succession.

(Fig. 4e). There are also successive secondary branching (sensu D'Alessandro \& Bromley, 1987) that suggest the reworking of a previous structure due to a re-entry of the tracemaker (Figs 4d, f). The fill is massive, red from haematite, distinguishing it from the host rock.

Remarks. Meanderovaleichnus huenickeni bears a certain morphological similarity to some examples preserved as negative epireliefs (epichnial depressions) of Ptychoplasma Fenton and Fenton, 1937, particularly with P. vagans (Książkiewicz, 1977). Ptychoplasma has been extensively revised by Uchman et al. (2011) and attributed to the locomotion of bivalves with a wedge-shaped foot. The main morphological features of $M$. huenickeni that resemble $P$. vagans are: I) orientation in plan view, straight to meandering or looping; II) the proportion of the width to the length; III) constrictions and swellings along the course, forming oval mounds in plan view; IV) similar distances between mounds in respect to the width and length; and V) sharp margins. However, $P$. vagans differs in that its hypichnial mounds are notably steep in cross-section. M. huenickeni is semi-circular in cross-section. In addition, it can be differentiated from $P$. excelsum Fenton and 


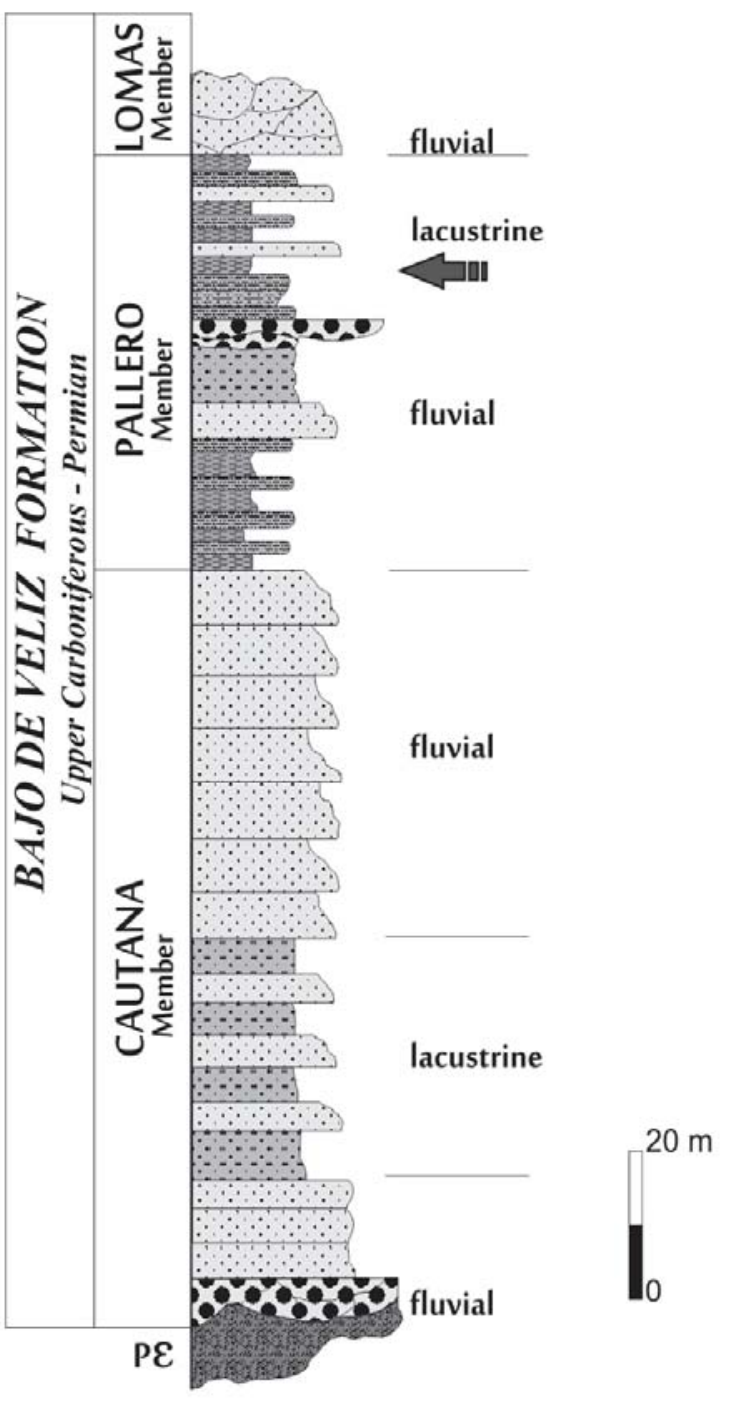

Figure 3. Integral stratigraphic section of the Bajo de Véliz Formation, showing the members and sedimentary settings (after Césari \& Hünicken, 1991). The arrow indicates the level from which Meanderovaleichnus huenickeni was collected.

Fenton, 1937 and from P. conica Pieńkowski \& Uchman, 2009 since these two ichnospecies have distinctive traces due to the 'relocation' of the bivalve's shell after each movement (Uchman et al., 2011, fig. 6) and that are lacking in this case.

The general plan, active fill, cross-section and especially the constrictions along the course of M. huenickeni show similarities to certain Planolites Nicholson, 1873 ichnospecies such as Planolites annularis Walcott, 1890 and ?Planolites reinecki Książkiewicz, 1977. P. annularis is horizontal, straight, sinuous, and exhibits prominent annulations. The annuli may be of regular or irregular size and spacing; otherwise; this burrow tends to be more or less constant in diameter (Pemberton \& Frey, 1982). Uchman (1998) reviewed the status of Planolites reinecki
Książkiewicz. Although Planolites reinecki was reservedly included in Palaeophycus alternatus Pemberton \& Frey (1982), the holotype of $P$. reinecki does not display a lining or any other features of Palaeophycus (sensu Uchman, 1998). Planolites constriannulatus isp. n. Stanley \& Pickerill, 1994 is distinguished for trace fossils that display the same features as $P$. reinecki, thus, $P$. constriannulatus is the junior subjective synonym of $P$. reinecki Książkiewicz (Uchman, 1998).

In the same sense can be mentioned -although passively filled- the constrictions and overall pathway of some annulated ichnospecies of Palaeophycus Hall, 1847: P. alternatus Pemberton \& Frey, 1982 and P. crenulatus Buckman, 1995. Buckman (1995) reviewed the status of these ichnospecies. P. alternatus is slightly curved in plan view and displays alternate annulate and striate section, and $P$. crenulatus is curved or sinuous in plan view, with continuous annulate ornament, which is more distinct than all other annulate ichnospecies of Palaeophycus (Buckman, 1995, fig. 7). Also P. annulatus Badve, 1987 and P. serratus McCann, 1993 (including P. anulatus sensu Buckman, 1995) respectively possess annulations that suggest an active mode of backfill, and consequently are considered nomina dubia by Buckman (1995). In wide sense the annulations in these ichnogenera presumably reflect peristaltic movements by the tracemaker, probably worm, to moving and/or feeding (sensu Pemberton \& Frey, 1982; Buckman, 1995 and references). Another ichnospecies that need to be considered is Torrowangea rosei Webby, 1970. T. rosei also exhibits a meandering course in plan view, with regularly distributed constrictions (Webby, 1970). It displays in some cases tight meanders, cutting previous structures and forming "nodes" (Webby, 1970, fig. 18B, C). In similar way that M. huenickeni, T. rosei is interpreted as burrow of worm-like deposit feeders (see discussion in Webby, 1970). The similarities between $M$. huenickeni and the mentioned ichnospecies of Planolites, Palaeophycus and Torrowangea could be related to a tracemaker with morphological and ethological affinities, using body parts that are not necessarily the same anatomically, even if they have a similar function and the end efficiency of the locomotion process is the same (see DISCUSSION). The most remarkable difference are the strong constrictions and swellings of M. huenickeni, which displays interconnected 'ovals' in plan view. Finally we need to consider the ichnogenus Halimedides Lorenz von Liburnau, 1902. Halimedides consists of straight to slightly curved, horizontal to oblique, tubular burrows, someplace with annulations and scratch marks on the burrow margin and a series of symmetrically distributed heart-shaped, angular, trapezoid, oval, semispherical, or bilobate chambers along its length (after Uchman, 1999; Gaillard \& Olivero, 2009). The chambers are used for food capture and storage, maybe used for microbial farming by the trace-maker - probably a small crustacean - in deep 


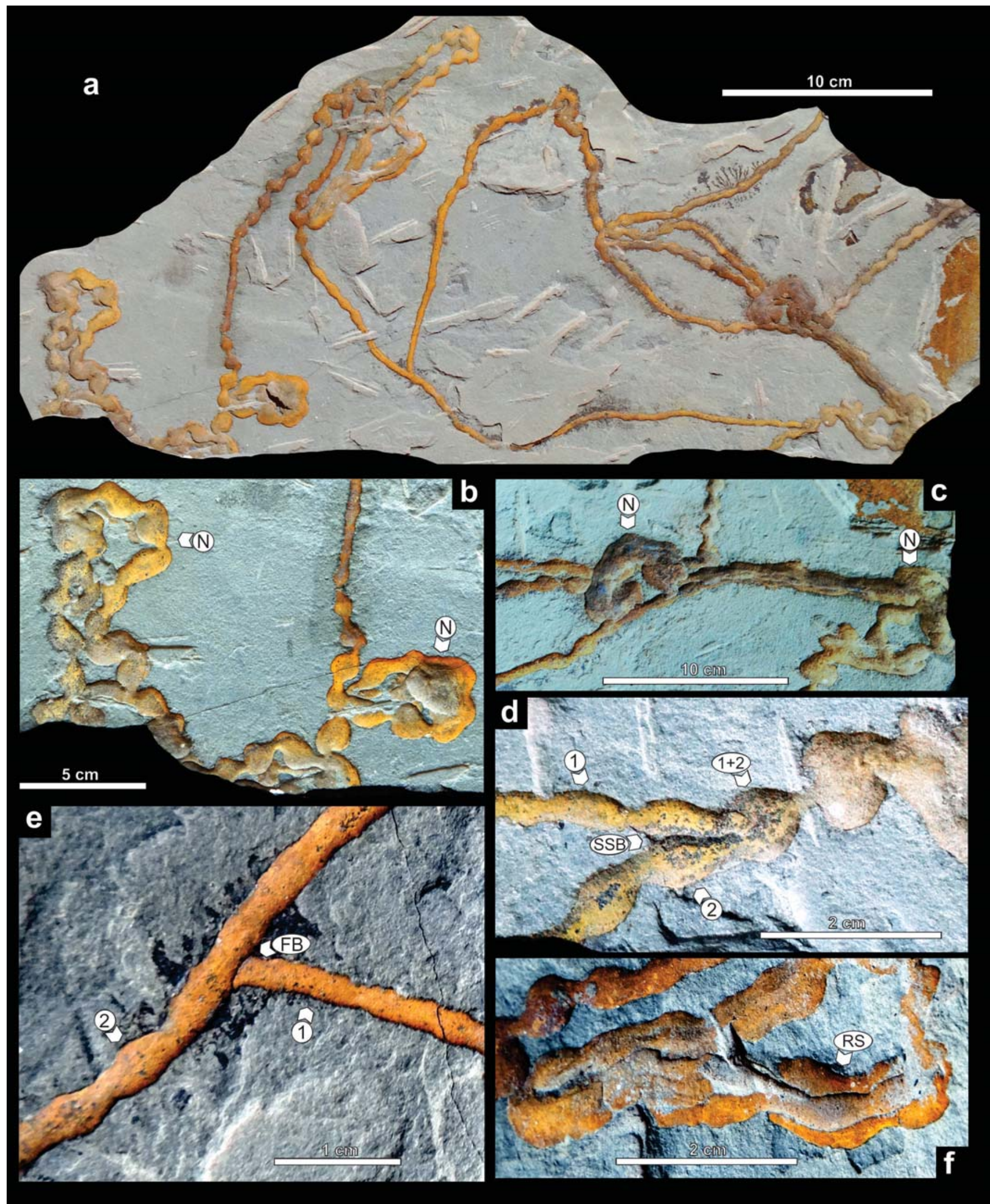

Figure 4. Meanderovaleichnus huenickeni from the Bajo de Véliz Formation, San Luis, Argentina. a) General view of holotype, PIL 15.769. b) Detail of nodes $(\mathrm{N})$ in trace course. c) Nodes $(\mathrm{N})$ cutting across pre-existing trajectories. d) Secondary successive branching (SSB). Course 1 is pre-existing. The organism moves nearby (course 2) and re-enters structure 1. From there, the resulting structure is deformed and wider $(1+2)$. e) False branching (FB). Course 1 is cut by course 2 . f) Reworked structure (RS). There is a pre-existing structure that contains a smaller, later structure within it. 
sea environments (Gaillard \& Olivero, 2009). Even though these constrictions and chambers in plan view resembling some parts of $M$. huenickeni, there are more differences than similarities. The morphology of each chamber in Halimedides suggest a different mode of construction and use - agrichnion - (sensu Gaillard \& Olivero, 2009). In Halimedides is common a high "chamber spacing", and are frequent lapses of course without chambers. Moreover M. huenickeni always displays constricctions and swellings along their course. Also, some Halimedides exhibit scratch marks, which are not observed in M. huenickeni.

\section{DISCUSSION}

\subsection{Trace construction}

Certain features presented above suggest the mode of construction: the general morphological plan of the trace, its meandering path, its orientation parallel to the bedding surface, the regular constrictions along the length of the course, fill and a semi-circular morphology in crosssection. These features are compatible with the scenario of a worm-like organism moving across the substrate by peristaltism. This mechanism was analysed in detail by Trueman (1975) and Seilacher (2007 and references) and involves in s.l. the following process: The head section of the worm digs into the substrate, inflates (forming a penetrating anchor), and then, through peristalsis, travels the length of the organism in a more-or-less continuous action, thereby pushing the animal forwards. In the case of $M$. huenickeni, there are two alternatives whose construction processes are interpreted in Figure 5. In the first alternative (Fig. 5a), which is the most common, the trace has maximum widths after each constriction, corresponding to the maximum possible dilation of the tracemaker's diameter. This configuration occurs when the worm is in a softer substrate with a consistency forcing it to anchor itself more effectively in order to progress. The second case is shown in Figure $5 b$. In this alternative, the trace displays a more regular width along the course. This suggests that due to a local increase in substrate consistency, the worm needs less effort to progress. This translates into less body dilation for anchoring during substrate penetration and therefore a more regular width to the trace. In overcrossing points (Figs $4 b-f$ ) the burrow crossing its earlier segment displays distinct margins. This shows that the earlier segment was already filled when was crossed by the later segment. This suggests an active filling just behind the tracemaker. The haematitic surface can be interpreted as differential alteration due to diagenesis and weathering, probably because of an original substrate change by the tracemaker (i.e. mucus secretion). In Figure 5, $L$ is the stride, which is the distance advanced by the worm during a peristalsis period (sensu Quillin, 1999). This dimension comprises the progress lapse in which the worm's parts advance over the substrate and the resting time during which the parts are holding onto the substrate.

\subsection{Tracemaker identity}

Based on its morphological and construction features, $M$. huenickeni is interpreted as a worm trace fossil produced during peristaltic burrowing. The term "worm" covers a wide variety of cylinder-shaped organisms from different phyla. Seilacher (2007) noted that annelids, molluscs (i.e., Natica, Polinices), and even anemones (i.e., actinians), among others, can employ similar mechanisms to travel across the substrate by peristaltism ("worm-type burrowing" sensu Seilacher, 2007). As to the identity of the possible tracemaker, the absence of traces of setae, cirri, or parapodia (that might have been preserved given the texture of the host rock) suggests (although not definitively) that we can discard earthworms (Lumbricidae) and a great number of polychaetes with these anatomical parts. For instance, rhythmic constrictions and 'scratches' are common in Scoyenia (which has an active infill). The locomotion inferred for it is similar to that of M. huenickeni although, as Seilacher (2007) mentions, there is still debate as to whether 'pure' peristalsis is compatible with active infill. As mentioned above, the absence of shell relocation traces suggesting gastropods and similar organisms can be discarded. It is highly likely that the $M$. huenickeni tracemaker was a coelomate worm-like organism with bilateral symmetry and a body axis oriented in the sense of movement, with cephalization and sensory organs. The coelomate feature is important since the hydrostatic pressure produced by the internal cavity is what allows peristaltic movement and therefore locomotion of the animal (Pechenik, 2010). It is likely it was a segmented organism, which makes peristaltism more efficient since the hydrostatic pressure of the coelom is evenly distributed to the individual segments or to groups of segments, which also allows energy savings compared to non-segmented worms (Turbeville \& Ruppert, 1983). These aspects suggest a link to Annelida although, given all the data, a definitive assignation is postponed until new material is found and/or new records are reported.

\subsubsection{Ethological classification}

As regards the interpretation of this trace fossil, and based on the information given above, we speculate on the following alternatives: 


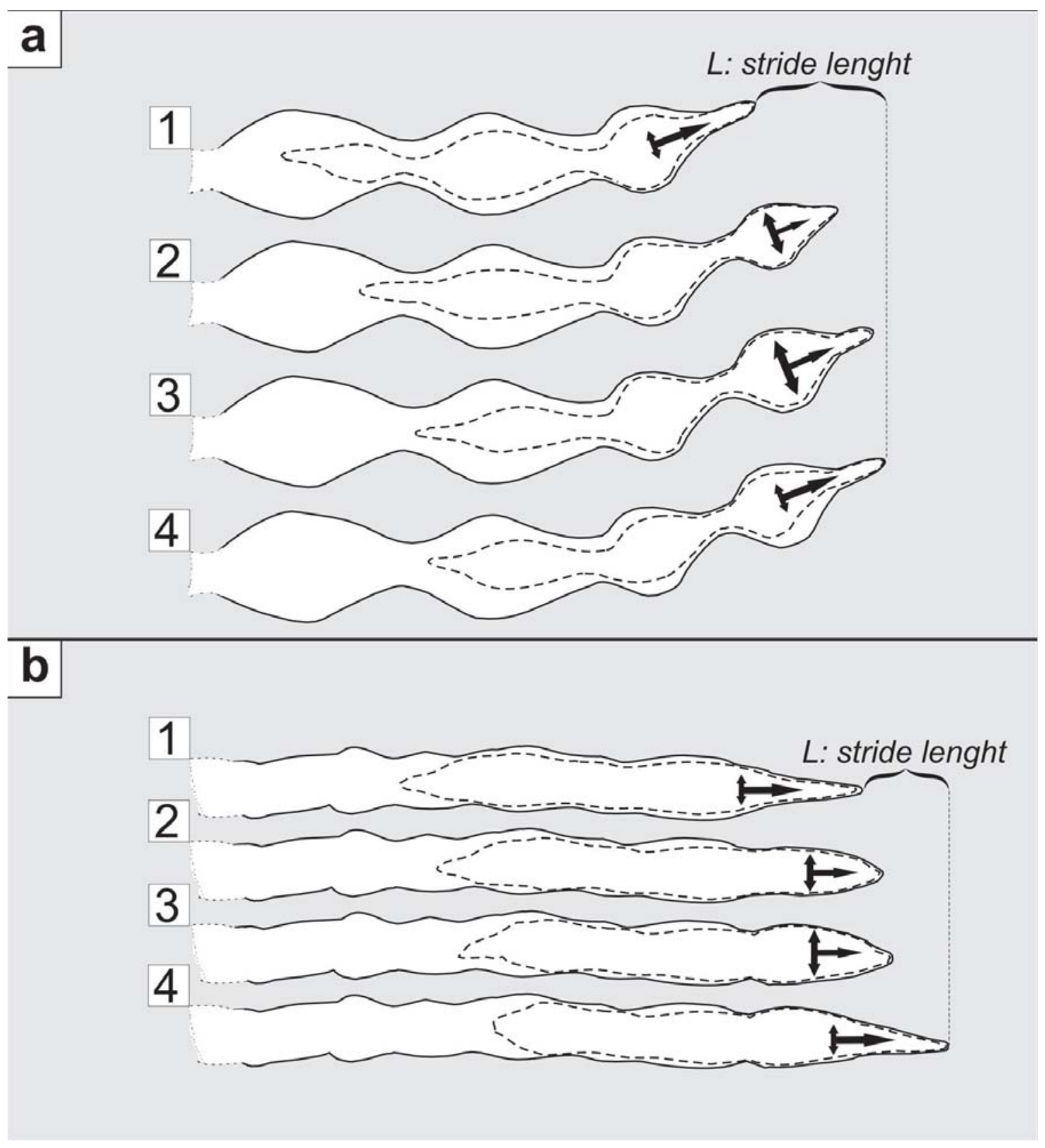

Figure 5. Construction patterns of Meanderovaleichnus huenickeni. a) Softer substrate. 1) The anterior part of the worm extends to the maximum possible and penetrates the substrate. 2) Advancing, the anterior part of the worm widens and anchors itself firmly to the substrate. 3) The maximum body width is reached. 4) The anterior part of the worm extends once again to penetrate the substrate. This completes one stride $(L)$. b) Increasing substrate consistency. In this case, stages 1 to 4 are analogous to A. Since the substrate is firmer, it requires less effort, and so the body dilation in each length does not need to reach the maximum possible body width.

1) Locomotion. The construction characteristics suggest a crawling trace (repichnion). 2) Shelter. It is possible these structures were produced by the trace maker in search of a burrow in addition to by simple movement. This strategy has been documented in some types of earthworms (anecic species) (Bastardie et al., 2002), which build subhorizontal burrows for protection from which they travel to the surface to feed.

\section{FINAL COMMENTS}

Meanderovaleichnus huenickeni is an ichnotaxon whose features suggest it is the product of peristaltic burrowing by a worm, probably a non-marine annelid. Ethologically it is a locomotion trace (repichnion) being a new element for the discussion of peristaltism as a locomotion mechanism in worm-like organisms. This is particularly 
interesting in the stratigraphic context of this first record from a unit characteristic of the South American Upper Paleozoic. Finally, we expect new records of M. huenickeni and of neoichnological analogues, which will certainly enable more discussion on the ichnotaxonomic and palaeobiological details of this trace fossil.

\section{ACKNOWLEDGEMENTS}

The authors would like to thank Jordi M. de Gibert, Mariano Verde and Carlos Molineri for their fruitful comments during the course of this work. Very special thanks go to Alfred Uchman, who reviewed a previous version of manuscript, and offered suggestions, comments and improvements on the final draft. Koji Seike is thanked also for his valued review. We would also like to express our appreciation to Mario Hünicken for providing the material presented herein. Finally, we are grateful to Silvana Urquiza for giving us support with the photographs. This contribution was financed by project 26/6401 - 1 (F.G. Aceñolaza) of the Research Council of the National University of Tucumán, Argentina.

\section{REFERENCES}

Badve, R.M. 1987. A reassessment of stratigraphy of Bagh Beds, Barwah area, Madhya Pradesh, with descriptions of trace fossils. Geological Society of India Journal, 30, 106-120.

Bastardie, F., Cannavaciuolo, M., Capowiez, Y., De Dreuzy, J.R., Bellido, A. \& Cluzeau, D. 2002. A new simulation for modelling the topology of earthworm burrow systems and their effects on macropore flow in experimental soils. Biology and Fertility of Soils, 36, 161-169.

Bertling, M., Braddy, S.J., Bromley, R.G., Demathieu, G.R., Genise, J., Mikulas, R., Nielsen, J.K., Nielsen, K.S.S., Rindsberg, A.K., Schlirf, M. \& Uchman, A. 2006. Names for trace fossils: a uniform approach. Lethaia, 39, 265-286.

Bromley, R.G. 1981. Concepts in ichnotaxonomy illustrated by small round holes in shells. Acta Geológica Hispánica, 16, 55-64.

Buatois, L. \& Mángano, M. 2011. Ichnology: OrganismSubstrate Interactions in Space and Time. Cambridge University Press, Cambridge.

Buckman, J.O. 1995. A comment on annulate forms of Palaeophycus Hall 1847: With particular reference to P. 'annulatus' sensu Pemberton and Frey 1982, and the erection of $P$. crenulatus ichnosp. nov. Ichnos, 4, 131-140.
Césari, S. \& Hünicken, M. 1991. Stephanophyllites sanpaulensis Millan y Dolianiti, un nuevo integrante de las floras neopaleozoicas de Argentina. Miscelánea, Academia Nacional de Ciencias, 83, 1-9.

D’Alessandro, A. \& Bromley, R.G. 1987. Meniscate trace fossils and the Muensteria-Taenidium problem. Palaeontology, 320, 743-763.

Fenton, C.L. \& Fenton, M.A. 1937. Burrows and trails from Pennsylvanian rocks of Texas. American Midland Naturalist, 18, 1079-1084.

Flores, M.A. 1969. El Bolsón de las Salinas en la provincia de San Luis. In: IV Congreso Geológico Argentino, Actas, 1, 311-327.

Gaillard, C. \& Olivero, D. 2009. The ichnofossil Halimedides in Cretaceous pelagic deposits from the Alps: environmental and ethological significance. Palaios, 24, 257-270.

Gibert, J.M. de \& Ekdale, A.A. 2010. Paleobiology of the crustacean trace fossil Spongeliomorpha iberica in the Micene of southeastern Spain. Acta Palaeontologica Polonica, 55, 733-740.

Hall, J. 1847. Palaeontology of New York. State of New York (Albany, N.Y.).

Hünicken, M.A. 1979. A giant fossil spider (Megarachne servinei) from Bajo de Véliz, Upper Carboniferous, Argentina. Boletin de la Academia Nacional de Ciencias, Córdoba, Argentina, 53, 317-341.

Hünicken, M. \& Pensa, M.V. 1972. Algunas novedades estratigráficas y tectónicas sobre los depósitos gondwánicos del Bajo de Veliz (San Luis). Boletín de la Asociación Geológica de Córdoba, 1, 317-341.

Hünicken, M. \& Pensa, M.V. 1981. Estratigrafía y tectónica de los depósitos gondwánicos del Bajo de Véliz, provincia de San Luis, República Argentina. Revista de la Facultad de Ciencias Exactas, Físicas y Naturales - Serie Ciencias Geológicas, 3, 1-37.

Hünicken, M., Azcuy, C. \& Pensa, M.V. 1981. Sedimentitas Paleozoicas. In: Geología y recursos naturales de San Luis. Relatorio $8^{\circ}$ Congreso Geológico Argentino (ed. Yrigoyen, M.), 1, 55-77.

Książkiewicz, M. 1977. Trace fossils in the flysch of the Polish Carpathians. Palaeontologia Polonica, 36, 1-208.

Lorenz von Liburnau, J.R. 1902. Ergänzung zur Beschreibung der fossilen Halimeda fuggeri. Sitzungsberichte der Akademie der Wissenschaften in Wien, Mathematischnaturwissenschaftliche Klasse, 111, 685-712.

McCann, T. 1993. A Nereites ichnofacies from the OrdovicianSilurian Welsh Basin. Ichnos, 3, 39-56.

Nicholson, H.A. 1873. Contributions to the study of the errant Annelids of the older Paleozoic rocks. Proceedings of the Royal Society of London, 21, 288-290.

Pechenik, J.A. 2010. Biology of the Invertebrates. McGrawHill, New York.

Pemberton, S.G. \& Frey, R.W. 1982. Trace fossil nomenclature and the Planolites-Palaeophycus dilemma. Journal of Paleontology, 56, 843-881.

Pienkowski, G. \& Uchman, A. 2009. Ptychoplasma conica isp. nov. - a new bivalve locomotion trace fossil from 
the Lower Jurasic (Hettangian) alluvial sediments of Sołtyków, Holy Cross Mountains, Poland. Geological Quarterly, 53, 397-406.

Prozzi, C.R. \& Ramos, G. 1988. La Formación San Luis. In: $1^{\circ}$ Jornadas de trabajo de Sierras Pampeanas, Resúmenes, 1, 1 p.

Quillin, K.J. 1999. Kinematic scaling of locomotion by hydrostatic animals: Ontogeny of peristaltic crawling by the earthworm Lumbricus terrestris. The Journal of Experimental Biology, 202, 661-674.

Sato, A.M., Gonzalez, P.D. \& Llambias, E.J. 2003. Evolución del orógeno Famatiniano en la Sierra de San Luis: magmatismo de arco, deformación y metamorfismo de bajo a alto grado. Revista de la Asociación Geológica Argentina, 58, 487-504.

Seilacher, A. 2007. Trace Fossil Analysis. Springer, Berlin

Selden, P.A., Corronca, J.A. \& Hünicken, M.A. 2005. The true identity of the supposed giant fossil spider Megarachne. Biology Letters, 1, 44-48.

Selden, P.A. \& Penney, D. 2010. Fossil spiders. Biological Reviews, 85, 171-206.

Stanley, D.C.A. \& Pickerill, R.K. 1994. Planolites constriannulatus isp. nov. from the Late Ordovician Georgian Bay Formation of southern Ontario, eastern Canada. Ichnos, 3, 119-123.
Trueman, E.R. 1975. The locomotion of soft-bodied animals. Edward Arnold, London.

Turbeville, J.M. \& Ruppert, E.E. 1983. Epidermal muscles and peristaltic burrowing in Carinoma tremaphoros (Nemertini): Correlates of effective burrowing without segmentation. Zoomorphology, 103, 103-120.

Uchman, A. 1998. Taxonomy and ethology of flysch trace fossils; Revision of the Marian Książkiewicz collection and studies of complementary material. Annales Societatis Geologorum Poloniae, 68, 105-218.

Uchman, A. 1999. Ichnology of the Rhenodanubian flysch (Lower Cretaceous-Eocene) in Austria and Germany. Beringeria, 25, 65-171.

Uchman, A., Mikuláš, R. \& Rindsberg, A.K. 2011. Mollusc trace fossils Ptychoplasma Fenton and Fenton, 1937 and Oravaichnium Plička and Uhrová, 1990: Their type material and ichnospecies. Geobios, 44, 387-397.

Walcott, C.D. 1890. Descriptive notes of new genera and species from the Lower Cambrian or Olenellus Zone of North America. U.S. National Museum Proceedings, 12 (1889), 33-46.

Webby, B.D. 1970. Late Precambrian trace fossils from New South Wales. Lethaia, 3, 79-109. 
